\title{
Sokak Sanatında Üsluba Dair Yorumlar ve Muhalif Boyut
}

Hamdi GÖKOVA*

Gökova, H. (2020). Sokak Sanatında Üsluba Dair Yorumlar ve Muhalif Boyut. YEDİ, 23, 97-107, doi: 10.17484/yedi.620033

Araştırma Makale / Research Article

Özet

Sokak Sanatı ismi, 90’larda grafitinin içinde belirginleşen şablon, çıkartma, mozaik, poster gibi yöntemlerle oluşturulan farklı uygulamaları nitelemek için kullanılmaya başlamıştır. Grafiti kendi dar grubuna seslenirken, sokak sanatı topluma hitap etmeyi ve mesaj iletmeyi amaçlıyordu. Sokak sanatı, reklamlarda yer alma, kamusal alanda yasal uygulamalar, müze ve galerilerde sergilemeler gibi etkinlikler aracılı̆̆ıla sisteme bulaştı̆̆ı anda tartışmalar başlıyor. Gelip geçiciliği, muhalifliği, vandallığı ve anonimliği savunan bir grup, yasal uygulamaları ve sergilerde yer almayı davaya ihanet olarak görürken, diğer bir grup ise, sanatsal kalite ve gelişim için bunu doğal karşılıyor. Sokak sanatı, son yıllarda gerçekleştirilen önemli sergiler, etkinlikler ve oluşan büyük ilgi nedeniyle çağdaş bir sanat akımı görünümündedir. Yeni bir izleyici kitlesi oluşturan sokak sanatı, kapalı devre çalışan mevcut sanat sistemine de açılım sağlıyor ve sanatı toplumla barıştırıyor. Bu çalışma, sokak sanatını üslup yönelimleri bağlamında belirli sanatçılar üzerinden inceleyip, muhalif boyutunu tartışacaktır.

Anahtar Sözcükler: Sokak sanatı, grafiti, vandalizm, kamusal alan, çağdaş sanat.

\section{Comments on Style in Street Art and Oppositional Dimension}

Abstract

The name Street Art began to be used to characterize different applications created by methods such as stencils, stickers, mosaics, posters, which became evident in the graffiti in the 90s. While graffiti addressed its own narrow band, street art aimed at addressing and communicating to society. Discussions begin as soon as it enters the system through activities such as street art, advertising, legal practices in public spaces, exhibitions in museums and galleries. While a group advocating temporality, opposition, vandalism and anonymity sees legal practices and participation in exhibitions as betrayal, another group regards this as natural for artistic quality and development. Street art looks like a contemporary art movement due to the important exhibitions, events and great interest in recent years. Street art, which forms a new audience, also opens up the existing closed-circuit art system and reconciles art with society. This study examines street art through certain artists in the context of their stylistic orientations and discusses the opposition dimension.

Keywords: Street art, graffiti, vandalism, public space, contemporary art. 


\section{Giriş}

Sokak sanatı deyimi günümüzde olduğu gibi belirli bir sanat hareketini işaret etmeden önce sokakta ve kapı dışında gerçekleştirilen etkinlikleri kapsayan geniş bir kavramdı. Bu deyim, özellikle son yirmi yıl içinde grafiti ve sokakta gerçekleştirilen sanatsal pratiklerdeki gelişmeler ve değişimler sonucunda şimdiki kullanım biçimine kavuştu. Bilindik anlamda grafiti, harflerle tipografik düzenlemeler yapmak, referans grupların beğenisini kazanmak, kışkırtmak istedikleri toplumsal grubu rahatsız etmek gibi amaçlarla kendi dar çevresine sesleniyordu. Grafitinin zaman içindeki değişim sürecinde şablon, sticker, mozaik, poster gibi değişik yöntem ve malzemelerin kullanıldığı çalışmalar ortaya çıktı.

İsmini şehre yayarak var olma eylemi olarak da tanımlayabileceğimiz graffiti, daha serbest bir kendini ifade etme sanatına dönüştü. Bu evrilmenin yeni ismi olan sokak sanatı, öncüsü graffitiyi de çatısı altına alarak teknik ve stillerin çeşitlendiği daha ucu açık bir disiplin olarak belirdi (Ayral, 2014, s. 11).

Writer (grafiti yazıcısı, grafitici) kelimesi yerini sanatçıya bıraktı, kendi kitlesine seslenmek yerine, topluma seslenir hale geldi. Bu aşamadaki çalışmalar hem estetik hem de mesaj yüklü içeriğiyle geleneksel grafitinin ötesini ya da sonrasını işaret ettiğinden bu süreç 'Post Grafiti' diye adlandırıldı. Bu esnada ismini duyurmaya başlayan Banksy eleştiri ve ironi yüklü çalışmalarıyla post grafiti sürecini belirleyen önemli bir isim oldu.

Sokak sanatı ya da kent sanatı, "bunalımdaki dünyada gençliğe çekici gelecek yıkıcı bir aura yayar - bu nedenle de sanayileşmiş dünyanın tüm büyük kentlerinde yaygınlaşan kitlesel bir olaya dönüşür. Akımın öylesine geniş bir kitlenin hoşuna gitmesinin nedeni, kışkırtıcı ve saygısız bir karşı kültür oluşudur" (Lemonie, 2014, s. 21). Bu sanat, kuralları hiçe sayması anlamında asi ve radikal, kamusal ve özel mülkü aşağılayıp değersizleştirmesi açısından ise vandalisttir.

Sokak sanatı gücünü ve etkisini yapıldığı çevreden alır. Hızla gerçekleştirilmesi gerektiğinden uygun teknik ve malzemenin seçimi, adrenalin patlaması ve geçiciliği bu sanatı var eden unsurlardır. Bu sanatın toplum tarafından hızla benimsenmesi ve küresel ölçekte yaygınlaşması, galericiler, müzeler ve yayıncıların dikkatini çeker. Böylece, gençliğe hitap eden markalar sokak sanatının estetiğinden kendi reklamları için yararlanmaya, kamusal alanlarda yerel yönetimlerin de desteğiyle legal uygulamalar yapılmaya, galerilerde ve müzelerde sergilemeler başlar. Paranın da devreye girmesiyle işin rengi iyice değişir. Birçok muhalif sokak sanatçısı bu durumu vandal iken satılmış ve davaya ihanet etmek olarak görürken, kimileri de hızlı çalışma zorunluluğunun, çalışmalarındaki mesajı ve estetik boyutu yeterince vurgulayamaması nedeniyle legal uygulamalara ve galerilerde sergilemelere olumlu yaklaşırlar.

Önemli bir diğer konu da popülerleşen sokak sanatının, kapalı devre ilerleyen çağdaş sanatın tıkanmışlığına çare olmaya başlamasıdır. Son on, on beş yıldır, dünyanın dört bir yanında müzelerde ve galerilerde düzenlenen birçok büyük sokak sanatı sergileri bu durumu gözler önüne seriyor.

Burada öncelikle grafitiden sokak sanatına evrilme süreci, daha sonra farklı tarz ve malzemelerle çalışan belirli sanatçılar üzerinden sokak sanatı tanitılacaktır. Sonraki bölümlerde bu sanatın legal - illegal, geçici - kalıcı, muhalif - uzlaşmacı gibi çelişkili durumları ele alınacak, çağdaş bir sanat akımına dönüşüp dönüşmediği ve hala muhalif olup olmadı̆̆ı sorgulanacaktır.

\section{Grafitiden Sokak Sanatına}

Grafiti de diğer toplumsal kökenli sanat hareketleri gibi 1960’ların sosyal çalkantıları içinde ortaya çıktı. New York’a özgü bir hareket olan grafitiyi ilk uygulayanlar, siyahiler ve Latin göçmenlerdir. Aslında geçmişi çok eskilere dayanan grafitinin 20. yüzyıldaki ilk örneği, II. Dünya Savaşındaki 'Kilroy was here/Kilroy buradaydı' sayılabilir. “Bu sözcükler Avrupa'ya çıkartmaya giden Amerikan askerlerinin ağzına, beynine takılıyor ve aralarında slogan gibi gezmeye başlıyor" (Baykam, 2016, s. 28). Tag atmak, yani takma ismini değişik malzemelerle (marker, sprey boya) ve tipografik düzenlemelerle, vagonlara ve sokaklara yazmak, zaman zaman bunlara figür, portre gibi görsel unsurları dahil etmek, 60 'lardaki grafiticilerin kendilerini ifade etme yöntemiydi. Aynı yılların Paris'indeki üniversite olaylarında ise grafiti, şablon, afiş gibi yöntemlerle, politik ve eleştirel bir mesaj ulaştırma aracına dönüşmüştür. Amerika'da da savaş karşıtı eylemlerde benzeri yöntemler kullanılmıştır. Dönem ruhuna paralel olarak 70'li yıllardaki siyasi duvar yazıları, Türkiye'deki erken grafiti örnekleri olarak gösterilebilir.

Siyasi bir içerik olmaksızın da insanlar dertlerini anlatabilmek için duvarları yazıyla doldurmuşlardır. Hatta Baudrillard grafitinin politik olmadığını düşünmektedir ve ona göre "graffitiler gettolarda yaşayan insanların, kentlerdeki ayaklanmalarının bastırılması sonucunda ortaya çıkmışlardır” (Baudrillard, 2016, s. 144). Bu bağlamda, 
duvarlara ve vagonlara kendi imzasını, izini bırakmak, mesajını diğer gruplara ulaştırmak ve bununla gurur duymak, grafiticilerin temel yaklaşımı olmuştur.

Grafiti ve sokak sanatının güdüleri çeşitlidir. Geçicilik kavramı temel itici güçtür. Mülke zarar vermek anlamında vandalizm önemli diğer etmendir. Çalışma eninde sonunda silinecek ya da üstüne yeni bir çalışma yapılacaktır. Yapan kişi bunun farkındadır ve tek tesellisi çalışmanın uzun süre yerinde kalabilmesidir. Sonuçta "yeterince uzun süre asılı duran, yanlış da olsa doğru olur” (Mimaroğlu, 2002, s. 9). Böylece çalışma amacına ulaşır. Bu anlamda sanatın kapalı bir mekânda izleyiciyle iletişime geçmemesindense elden çıkarılabilir ve kullanıldıktan sonra atılabilir nitelikte olması tercih nedeni haline gelir.

Grafiti, sokakta yaşama kültürünün bir parçasıdır. Bu bağlamda sokaktaki break dance, rap/hip hop ve kaykay - Amerika, punk/rock - Avrupa kültürüyle organik bir bağ içindedir. Yasaklara karşı çıkan, asi ve aykırı gençliğin kendini ifade biçimidir. Vandal bir eylem olması nedeniyle yakalanmamak için hızlı çalışmanın yol açtığı adrenalin patlaması, gençlik için en temel itici güçtür. Bu heyecanı yaşayan bir writer için çalışmanın geçiciliğinin bir önemi yoktur. Gelip geçicilik durumu nedeniyle grafiticiler olabildiğince çalışmalarını belgelemeye çalışırlar; kendileri veya başkaları aracılığıyla. Bu bağlamda ilk olarak fotoğrafçı Brassai 1930'lardaki duvar çizim ve yazılarını günümüze ulaştırdı. Martha Cooper ve Henry Chalfant 70'lerin grafitilerini ve sanatçılarını belgeleyerek Subway Art (1984) kitabında topladılar. Bu kitap grafiticilerin temel başvuru kaynağı haline geldi. Daha sonra yayınlanan Spray can (1987 H. Chalfant - James Prigoff) kitabı da ilgi gördü. Ayrıca grafiticileri sanat dünyasına ilk lanse eden, 1981-85 arasında faaliyet gösteren Fun Gallery’dir. Bu galeri;

Sanat ortamlarına daha aşina ama sokakta da izini bırakan Kenny Scharf, Keith Haring, Jean Michael Basquiat gibi isimlerin yanı sıra grafitinin öncü isimlerinden Fab 5 Freddy, Lee Quinones, Dondi, Lady Pink ve Futura'ya sergilerinde yer verdi...yıllarca graffitici, rapçi ve break dance'çileri küratörler, koleksiyonerler ve sanat eleştirmenleriyle bir araya getirdi (Ayral, 2014, s. 12).

70’lerde kapalı devre çalışan sanatsal mekanizma dışında kalan ve galerilere kendini kabul ettiremeyen sanatçılar da sokağa ve kapı dışı sanatına yönelmişlerdir. Kimileri duvar resmi çalışma grupları oluşturmuş (William Walker gibi), kimileri de grafitiyle eleştirel biçimde kendilerini ifade etmişlerdir. Bunlardan biri Rene'dir (Rene Moncada). 1986 yılında New York'ta bir duvara boylu boyunca 'I am the Best Artist: Ben en iyi Sanatçıyım’ diye yazmıştır, “biri de gelip duvarın bir köşesine o ürkütücü soruyu çiziktirmişti: Öyleyse en iyi galeri sahibi kim?” (Mimaroğlu, 2002, s. 11).

Grafitiden sokak sanatına geçiş süreci keskin bir hatla ayrılamaz. Sokak sanatının bünyesinde grafiti ve onun materyalleri daima yer almıştır. Günümüzde pek çok sokak sanatçısı yazıyla düzenlemeye çalışmalarında yer vermekte, hala temel biçimlendirme malzemesi olarak sprey boyayı, markeri kullanmakta ve stilize bir biçimlendirme yöntemine başvurmaktadır. Anonim kalma ve takma isim kullanma geleneği sürdürülmektedir. Gelip geçicilik, adrenalin patlaması, hızlıçalışma, yerleşik kamusal ve sanatsal değerleri umursamamak da sokak sanatının düsturlarındandır. Sokak sanatını icra edenler de grafiticiler gibi büyük oranda illegal ve vandalist yaklaşımlar sergilerler. Ancak uygulamaları kısa sürede gerçekleştirmek için hazırlıklarının büyük kısmını geleneksel sanatçılar gibi stüdyoda tamamlarlar. Hatta şablon uygulayıcıları fon atmak da dâhil olmak üzere çalışmalarını birkaç seansta ve günde ancak bitirirler. Uygulama yasal değilse hız ve yakalanmamak esastır.

\section{Sokak Sanatının 1980’lerdeki Erken Öncüleri}

Grafitiden farklılaşmaya başlayan çalışmaların 80'lerdeki erken öncüleri olarak Keith Haring (1958-1990) ve Jean Michael Basquiat (1960-1988) gösterilebilir. Her iki sanatçı da A. Warhol tarafından desteklenerek, sokaktan profesyonel sanat ortamına taşındılar. Basquiat ilk başta 'Samo' takma adıyla yaptığı grafitilerle adını duyurmuştur. Galeri çalışmaları Art Brut (Ham Sanat) çağrışımlı, dışavurumcu niteliktedir. Yazı ve resim bileşimli çalışmaları büyük ilgi görmüştür. Adı 80’lerdeki yeni dişavurumcu sanatçılarla birlikte anıldı. Yüksek dozda aldığı uyuşturucu nedeniyle 28 yaşında öldü.

Keith Haring, çok yönlü kişiliğiyle toplumsal konulara duyarlı bir aktivist, piktogramı çağrıştıran grafik çizimleriyle etkili bir sokak sanatçısıydı. Çalışmalarını, insan vücudu da dâhil olmak üzere, her yüzeye uyguluyordu. "Keith Haring New York sokaklarında, özellikle metro istasyonlarında, duvar panolarının üstüne çizdiği, daha doğrusu çiziktirdiği bebek figürü ve havalı ‘çöpten adam' figürleriyle ünlendi. Emekleyen 'Radiant Baby' onun simgesi haline gelmişti” (Baykam, 2016, s. 114). Toplumsal duyarlılığı, aktivist kimliği ve yalın ifade tarzı nedeniyle Banksy’nin de onun adımlarını takip ettiği 
söylenebilir.

Haring ve Basquiat gibi 80’lerde adını duyurmuş diğer iki önemli sanatçı Futura ve Blek Le Rat’tır. Blek Le Rat (Xavier Prou), hem Banksy’ye, hem de tüm günümüz şablon sanatçılarına öncülük etmiştir. Paris'in ilk sokak sanatçısı ve uluslararası şablon sanatı hareketinin kurucusudur. 80'lerin başında Paris sokaklarını, kendisinin simgesi haline gelen fare figürleriyle donattı (bkz. Şekil 1).

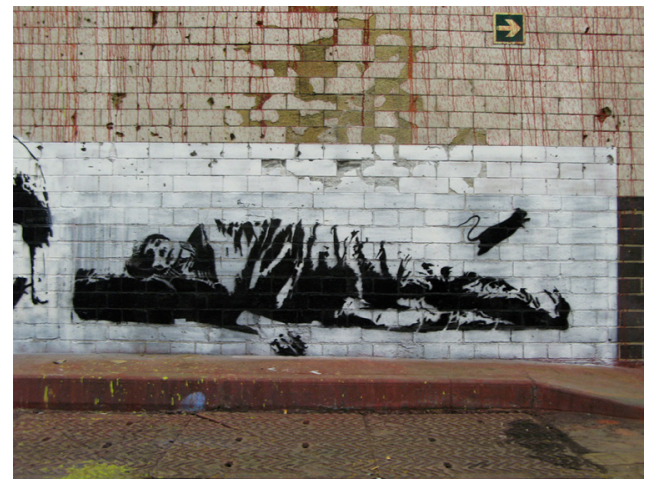

Şekil 1. Uyuyan Adam, Blek Le Rat, 2008.

Ona göre kiyamette de hayatta kalan tek hayvan sıçandı. Çalışmaları 2000'lerle birlikte daha sosyal ve politik boyut kazandı. Kentsel alandaki yalnız bireyler, evsizler ve dilencileri betimleyen çalışmalar gerçekleştirdi. Şablonun yanı sıra hızlı ve birden fazla uygulama olanağı nedeniyle poster çalışmaları da yapmaktadır. Banksy bu sanatçıdan oldukça etkilenmiş ve alıntılar yapmıştır (Blek Le Rat, t.y.).

Futura (Nick name/Takma isim) Futura 2000 diye de anılan Leonard Hilton McGur, 1970'lerin başında metro vagonlarına yazarak grafitiye başladı. Kısa sürede soyut resimsel bir üslup geliştirdi ve bununla tüm bir vagonu boyayan ilk grafitici oldu. “1970 ve 1980’lerde pek çok grafiti sanatçısı harf odaklı çalışmalar yaparken, Futura soyut tarzıyla grafitiye farklı bir soluk getirmiştir (bkz. Şekil 2).

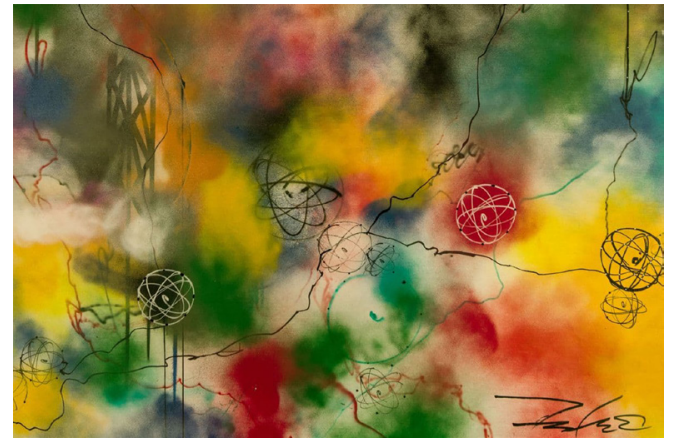

Şekil 2. İsimsiz (detay), Futura/Futura 2000, t.y. 1980’lerde, tuval üzerine çalışmalar da yapmaya başlayan sanatçının eserleri Keith Haring, Jean-Michel Basquiat ve Kenny Scharf gibi Amerikalı sanatçılarla birlikte sergilenmiştir” (Ayral, 2014, s. 119). 80’lerde punk grubu The Clash ile hem tasarım hem de performans anlamında ortak çalışmalar yapan sanatçı, ünlü şirketlere (Nike, Recon vb.) de tasarımlar yapmıştır. Halen Futura Laboratories için giysiler tasarlamaktadır. Tasarım stüdyosu sahibi ve marka olması nedeniyle radikal grafiticiler ve sokak sanatçıları tarafından eleştirilmektedir.

\section{Sokak Sanatı; Belirli Sanatçıları ve Sanatsal Yaklaşımları}

Sokak sanatı ismini ilk olarak 1985'te Allan Schwartzman, 'Street Art' adlı kitabında kullanmıştır. Bu deyim, 90'larda Invader'ın mozaik uygulamaları, Zeus'un 3D (üç boyutlu grafiti) ve logo uygulamaları ve Andre'nin çizgisel tiplemeleri gibi farklı malzeme ve yöntemle gerçekleştirdikleri çalışmaları nitelendirmek için gerekli hale gelmiştir. Bu çalışmalar estetik ve plastik kaygı taşımaları ve sahip oldukları sanatsal boyut nedeniyle 'Sokak Sanatı' diye nitelendirildiler.

$\mathrm{Bu}$ sanat geniş kapsamlı ve çok sayıda sanatçıyı içerdiğinden burada sokak sanatı dünyasında genel kabul görmüş sınırlı sayıda sanatçı, teknik yöntemleri ve üslup yönelimleri bağlamında ele alınacak ve incelenecektir.

Obey (Shepard Fairey) 1989 yılında Rus boksör Andre'nin portresini kullanarak bir karakter oluşturdu. “Henüz Rhode Island Tasarım Okulu öğrencisiyken yarattığı 'Andre the Giant Has a Posse / Dev Andre'nin Ekibi Var' yazılı sticker ve şablonlar hızla her yere yayıldı" (Ayral, 2014, s. 13). (bkz. Şekil 3).

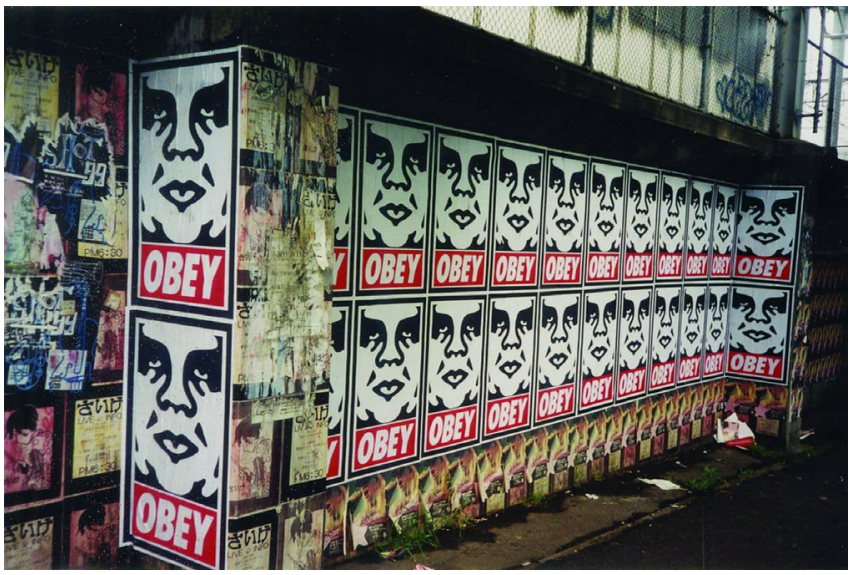

Şekil 3. Pasteup, Unknown, Obey, 1999

Daha sonra reklam yapma fikrini sorgulayarak 'Obey' 
(İtaat et) kelimesiyle, Andre portresini birleştirdi ve sticker (çıkartma), poster ve duvar çalışmalarında kullandı. Sanatçı bundan sonra Obey takma ismini kullanmaya başladı. Obama'nın seçim kampanyasında kullanılan portresini (umut) tasarlayarak tartışma yarattı ve popüler oldu. Bant dergisinin kapağı için de bir Atatürk portresi tasarlayan Fairey bugün şirketleri ve mal varlığı nedeniyle Banksy gibi tartışmalara konu olmaktadır. Tasarımcı ve sokak sanatçısı, grafiti yazarı Tristan Manco, Obey'in markalaşmasına olumlu yaklaşır:

Obey ve Futura grafiti çalışmalarının gücüyle tasarım stüdyolarını sürdüren ve markalaşan isimler. Bence onların geçmişte sokak üzerinde işlerini tasarlamış olmalarının verdiği tecrübe bugünkü işlerini çok olumlu yönde etkiliyor...Obey’in hikayesi ayrı bir fenomen çünkü Obey bu işe reklam yapma fikrini sorgulayan bir tavırla girdi, bugün baktığımızda ise başlı başına bir marka olarak karşımızda duruyor (Manco, 2006, s. 22).

Sokak sanatı kavramının ortaya çıkmasında ve yerleşmesinde Banksy'nin rolü büyüktür. Banksy sokak sanatına geçişi sağlayan post grafiti sürecini neredeyse tek başına belirlemiş ve sokak sanatı kavramının yerleşmesini sağlamıştır. Çalışmalarında eleştiri, mizah ve ironi kavramlarını basit ama etkili bir görsel dille (şablon/stencil) birleştirmiş, güncel iletişim olanaklarını (internet) da devreye sokarak, ezber bozan, alternatif bir sanat yaklaşımı ortaya koymuştur (bkz. Şekil 4).

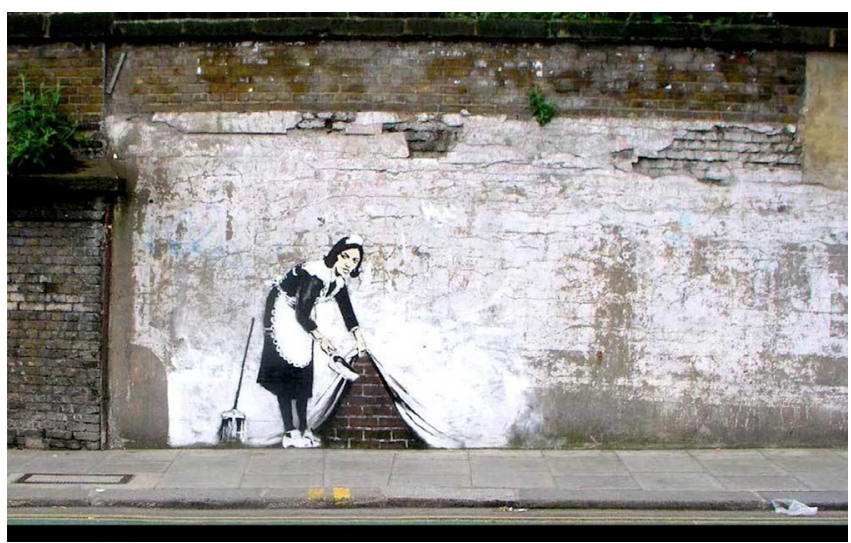

Şekil 4. Maid in London / Londra'da hizmetçi, Banksy, 2006.

“0 hem sanatçı, hem de büyük bir karikatüristin mizahıyla toplumu yorumlayan biri” (Jones, 2015, s. 12). Banksy, post modern süreçteki sanatsal yaklaşımların farkındalığı içinde çalışmalarını gerçekleştiriyor. Warholl'un Marylin ikonunu alıntılayıp yerine kendi çağının Kate Moss'unu koyarak pop art kavramına yeni bir yorum getiriyor, sanatla ilgisi olmayan yeni bir kitleyi sanat izleyicisi haline getiriyordu.

Sanatla ilgilenmeyen ve artık sokak sanatı üzerinden sanatla buluşan bir nesil vardı. Bu insanlar özgün Warhol'a, Warhol'un Banksy versiyonu üzerinden erişeceklerdi. Bence bu çok Warholvari bir düşünce...sondan başa doğru ilerleyen bir düşünce olduğu için zekice. İnsanlar buna bakıyorlar ve Warhol'u öğreniyorlar. Bu düşüncede az da olsa tahrip edici bir şey var (Jones, 2015, s. 200).

Invader Banksy gibi gerçek ismini gizlemektedir. Güzel Sanatlar ve Sorbonne üniversitesi'nde okudu. Çalışmalarını 1970’lerin bilgisayar oyunlarının kaba piksellerinden hareketle, bunlara en uygun malzeme olan seramik parçalarıyla mozaik biçiminde gerçekleştirmektedir. İsmini yine bu dönemin atari oyunu Space Invaders'dan (Uzay İstilacıları) almıştır (bkz. Şekil $5)$.

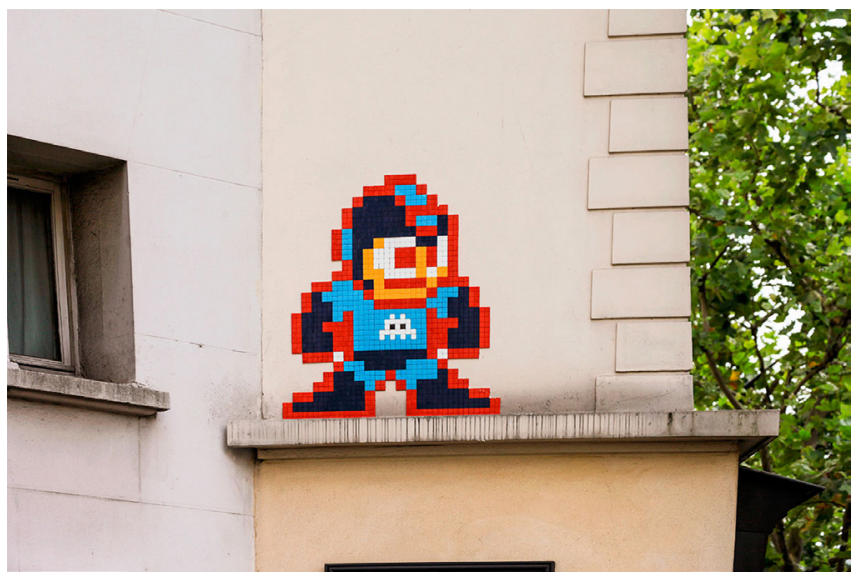

Şekil 5. Paris’te Yeni İstilalar, Invader, 2013.

Başlangıçta bu filmlerdeki karakterleri kullandı, daha sonra kendi özgün karakterlerini tasarladı. 1998'den beri Space Invader projesini geliştiren sanatçı önce Paris’te daha sonra ise dünyanın dört bir yanından belirlediği şehirlerin kritik noktalarına (kendisi buralara sinirsel noktalar demektedir) istilacılarını monte etmektedir. Bunun için önceden keşif yapan ve uygulayacağı sayıyı belirleyen sanatçı, amacının sürekli ve huzursuzca yeni yerler istila ederek, yeryüzündeki istila alanları puanını arttırmak olduğunu söylüyor. Politik bir tavrı olamadığını, fakat yerleştirmelerini \% 99 yasadışı yollarla yaptığı için zaten politik sayıldığını 
söyleyen sanatçı, politik muhalefetten ziyade sanatsal deneyimin içinde yer almayı önemsiyor. Sanatı müze ve kurumlardan özgürleştirmeyi, sokağa çıkarmayı, insanları şaşırtmayı ve akıllarda iz bırakmayı sevdiğini söylüyor. Kendini tanımlanamayan özgür bir sanatçı olarak tarif eden Invader, Banksy gibi kimliğini ve yüzünü gizliyor (Invader, t.y.).

Zeus (Dean Zeus Colman), 3D (Üç boyutlu) grafitinin öncüsü İngiliz sokak sanatçısı. Son 30 yılda kent kültüründen ilham alıp, dinamik ve deneysel kompozisyonlar oluşturarak grafitiyi yeniden tanımladı. 80'lerde üretken bir writer olarak ün kazandı ve hip hop otoritelerinin dikkatini çekti. Onun çalışmaları grafiti, tipografi, güzel sanatlar ve heykel sanatının yenilikçi bir bileşimidir (bkz. Şekil 6). Bu bileşim hem Chelsea Sanat Koleji’nden aldığı eğitimi hem de sokaktaki geçmişini yansıtır.

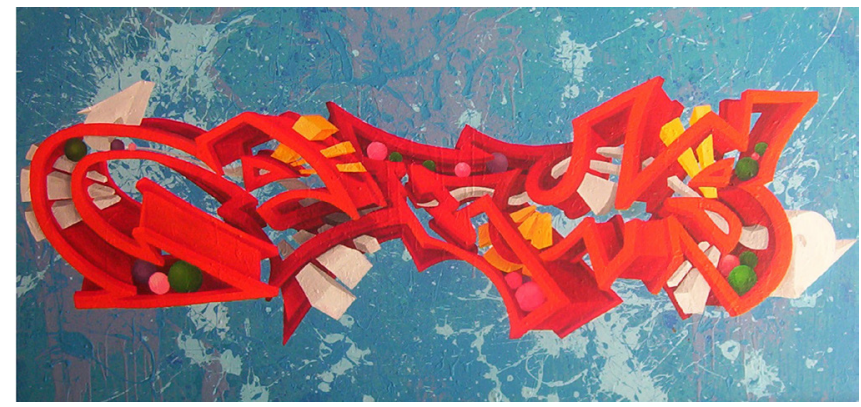

Şekil 6. 3D Duvar, Zeus, t.y.

Grafitiyi kentsel etkiler ve karmaşık mimariyle birleştirir. Bu izleyici için bir zekâ oyununa dönüşür. Zeus lisans tamamlama eğitimini heykel üzerine yapar ve bu sanatını üçüncü boyuta taşır, böylece ahşaptan üç boyutlu grafiti heykeller yapmaya başlar. Bu çalışmalar incelikli bir el sanatıyla, mükemmel bir biçimde ve dikkatlice oluşturulmuştur. Çalışmaları her zaman iyi ve nitelikli bir mizah dozuna sahiptir (Zeus, 2012).

JonOne (John Andrew Perello), başlangıçta tren ve duvarlara Jon 156 imzasını atarak grafitiye başladı. 1987'de Paris'e taşındı. Kent ortamının hareketli yapısı ve dokusundan etkilenerek 1980’lerde soyut çalışmalara yöneldi. Çalışmaları Jackson Pollock ve Jean Dubuffet'yi çağrıştıran soyut dışavurumcu bir çizgide yer alır. Paris'e taşındıktan sonra tuval çalışmalarına başlayan sanatçı, dünyanın dört bir yanında kişisel sergiler düzenledi ve karma sergilere katıldı. JonOne sanatını grafitinin soyut bir ifadesi olarak görüyor ve şöyle tanımlıyor: "Sanatım patlamaya hazırdır, kendi dünyamın gerçekliğini soyut bir biçimde ifade eder, tarzı serbesttir, renk, biçim, enerji ve uyumun serbest tarzda bileşimidir. İşimin uzun bir tarihi var ve her zaman evrilir, asla aynı kalmaz" (Ayral, 2014, s. 175). Jon0ne, Futura, KR (Craig Costello), Carlos Mare (Carlos Rodriguez) gibi sanatçılarla birlikte soyut grafitinin önemli bir temsilcisidir (bkz. Şekil 7).

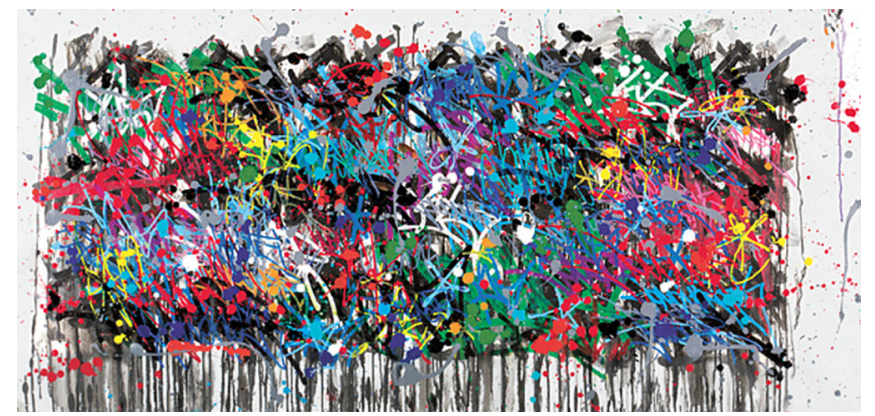

Şekil 7. Gözlerini Aç, JonOne, 2016.

Evol (Tore Rinkweld) Berlin'de yaşayan ve çalışan sanatçı, Arts \& Crafts (Sanat ve Zanaat) ve ürün tasarımı eğitimi aldı. Bu sayede atık mukavva ve ambalaj gibi malzemelerle, boyama, kâğıt yapıştırma ve stencil yöntemlerini de devreye sokarak, minyatür kentsel mekân yerleştirmeleri gerçekleştirdi (bkz. Şekil 8).

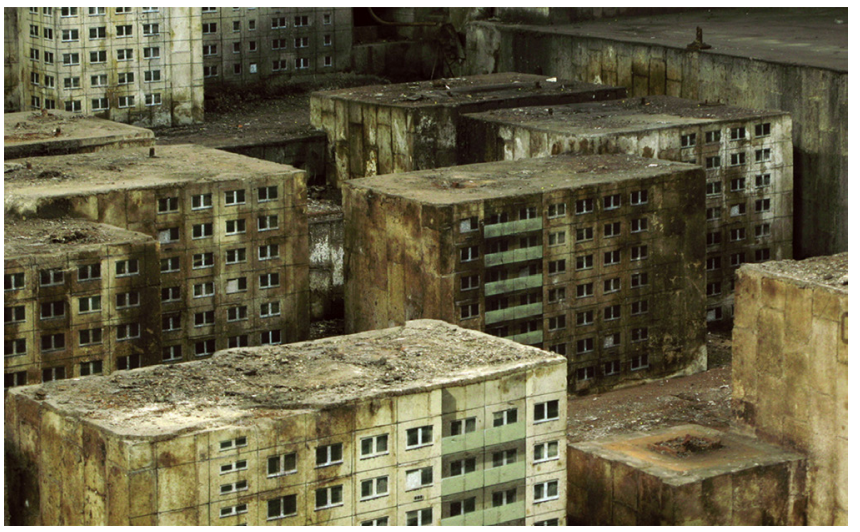

Şekil 8. Caspar David Friedrich-Stadt I, Evol, 2009.

İki Dünya savaşı arasındaki Berlin binaları projesi dikkate değerdir. Sokakta ise yine bu teknik yöntemler aracılığıyla, elektrik kutusu, parke taşları gibi sokak demirbaşlarını mimari yapılara dönüştürdü. Bu çalışmalar etraflarındaki büyüklüklerle zıtlık oluşturduğundan şaşırtıcı bir görsel etki yaratıyorlardı. "Sanatçı kendi ifadesiyle, 
'gündelik şeylere başka bir algı yüzeyi ekliyor'. Böylece izleyicinin iş, nesne ve dünyanın kendisine dair anlayışlarını yeniden düşünmelerine sebep oluyor” (Ayral, 2014, s. 169). Sanatçı stüdyo çalışmalarıyla ulusal ve uluslararası sergilere, sanat fuarlarına katılıyor.

JR (Jean Rene) fotoğraf temelli çalışmalarına, 2001'de Paris metrosunda bulduğu bir kamerayla başladı. Kendini duvarlarda ifade edenlerle tanışmak ve onların fotoğraflarını çekmek için Avrupa turuna çıktı ve onların portrelerini Paris metrosu ve sokaklarına astı. Onun yöntemi, yasadışı siyasi afişlemeye benzer. JR, Paris gecekondularına, Orta Doğu Duvarlarına, Brezilya'daki Favela'lara (kenar mahalle) davetsiz bir biçimde yayılan 'Yaygın Sanat' yapıyor (bkz. Şekil 9).

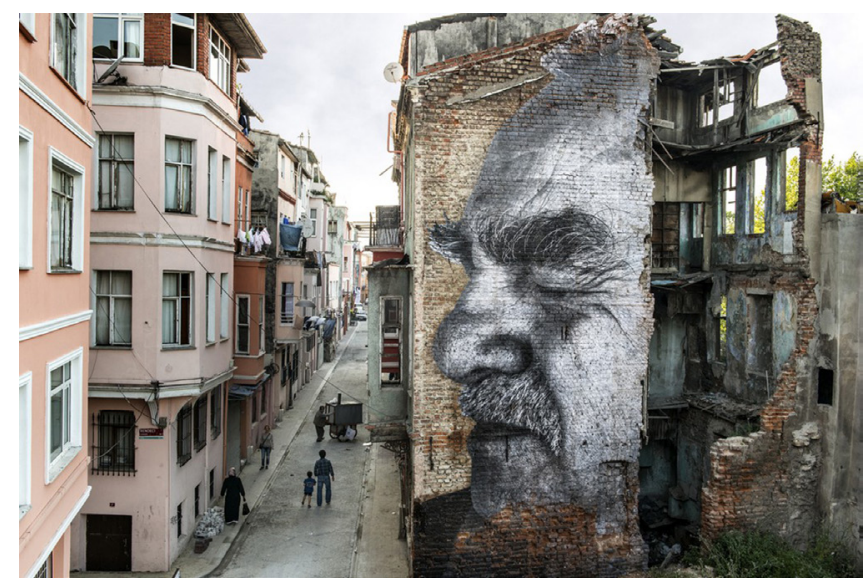

Şekil 9. Kentin kırışıklıkları, JR, 2015.

Buradaki yoksul insanlar çalışma sürecine katılırlar, bazıları bir günlügüune model olurken bazıları da bir haftalığına sanatçı olurlar. JR anonim kalarak (gözlük ve şapka kullanıyor) ve yüzlerini kullandığı insanları da anonimleştirerek, konu ile izleyici arasındaki karşılaşma için boş bir alan bırakıyor. Başlıca projeleri: (Bir neslin portresi/ Portrait of a generation), (Yüz yüze/Face to face), (Kadınlar kahramandır/Women are heroes) ve uluslararası katılımlı (Tersyüz/Inside out) dür. Sanatçı ayrıca 2016 Olimpiyat Oyunları için Rio de Janerio'da atletik hareketin güzelliğine vurgu yapan devasa foto yerleştirmeler gerçekleştirdi. Yine aynı yıl anamorfik foto yerleştirmesiyle, Louvre'un ünlü piramidini gizlemeye çalıştı. 0 da pek çok sokak sanatçısı gibi galeri ve müze sergi çalışması yapıyor (JR, t.y.).

Swoon (Caledonia Curry), Brooklyn'de yaşıyor ve çalışıyor. Erkek egemen sokak sanatı dünyasında, geniş çaplı tanınırlığa sahip ilk kadın sanatçı olarak biliniyor. 19982001 yılları arasında Pratt Sanat Enstitüsü’nde eğitim aldı. Bu esnada New York sokaklarında, sanatı kamusal alanlarda daha erişilebilir kılmak için kâğıt portrelerini duvarlara yapıştırmaya başladı. Bu figürleri, çizim, baskı resim, kesme çıkartma gibi birçok tekniği kullanarak duvarlara afiş yapıştırma yöntemleriyle sabitliyordu. Bu şekilde tasarladığı figür kompozisyonlarını üç boyutlu yerleştirmelerinde de kullandı. Çağdaş sanat çoğu zaman estetik kavramıyla çelişirken onun çalışmaları güzellik kavramını yüceltmeye eğilimlidir. Kompozisyonlarının temaları peri masalları, efsaneler ve kutsal kadınsılığın yinelenen motiflerinden oluşur (bkz. Şekil 10).

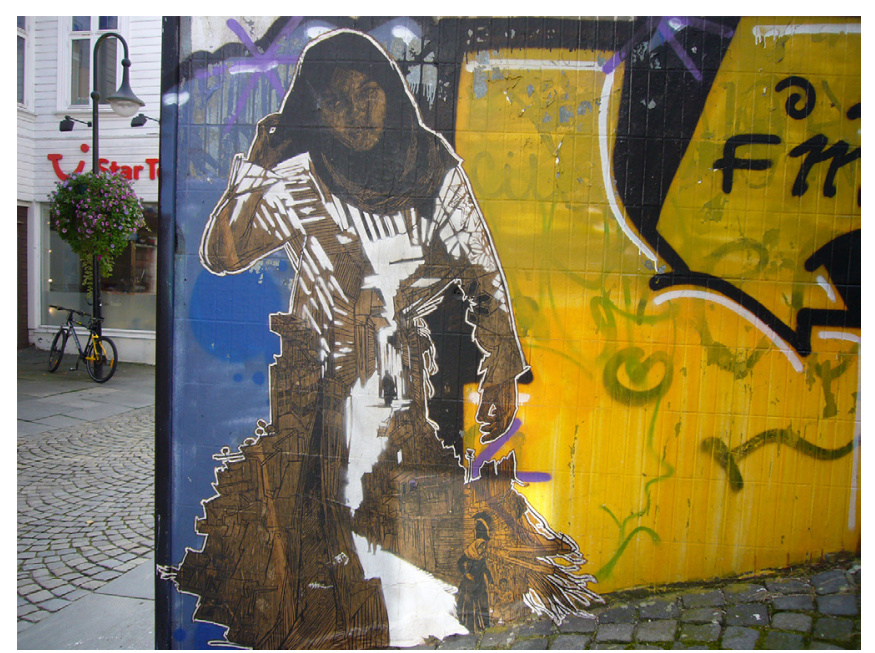

Şekil 10. İsimsiz, Swoon, 2009.

Sanatının çoğu fantastik olsa da güçlü bir gerçekçilik unsuru barındırır. Sosyal sorumluluk projelerinde de yer alan sanatçının çalışmaları dünyanın dört bir yanında duvarlarda ve çeşitli çağdaş sanat müzelerinde kalıcı ve geçici olarak bulunur. Son zamanlarda görsel öykü anlatıcılığının sınırlarını keşfetmek için animasyon film yöntemlerine başvurmaktadır (Swoon, t.y.).

\section{Sokak Sanatı Üzerinden Duvar Resminin (Mural) Yeniden Doğuşu}

Çok eskiden beri var olan kamusal alandaki ısmarlama duvar resimleri, sokak sanatının popülerleşmesiyle 2010’lu yıllarla birlikte yeniden gündeme gelir. Bu durumun, sokak sanatını ehlileştirme çabalarının sonucunda ortaya çıktığı 
söylenebilir. Kimi sokak sanatçıları da kendilerini daha iyi ifade etmek ve daha nitelikli bir görsel sonuca ulaşmak için yasal uygulamaları tercih etmeye başlayınca böyle bir süreç başlamıştır. Ticari oyunun kuralları benimsenince, aracı kurumlar; belediyeler, paydaş firmalar, galeriler gibi ticari işletmeler yeni bir meslek perspektifi sunmuş, grafiti ve sokak sanatı okullarda eğitimi verilir hale gelmiştir. 2010'dan beri bu profesyonelleşme festivalleri ve 'Anıtsal siparişleri’ doğurmuştur. Muralissimo/Muralizm (bilindik anlamıla Duvar Resmi) “özünde, belediyelerin düzenlediği festivallerde büyük boyutlu duvarlara resim yapılmasıdır. Bu festivaller herhangi bir kural çiğneme ya da kışkırtıcılık olanağı vermez, dolayısıyla yasalara uyan genç freskçileri ilgilendirir” (C215/Guemy, 2014, s. 36). Bu şekilde desteklendiğinde bu çalışmaların büyük sokak süsüne dönüşme riski ortaya çıkmıştır ki bunların örnekleri mevcuttur. Sokak sanatçılarının moda bir tabirle, 'Mural yapıyorum' dediği bu çalışmalar, biçimlendirme ve konuya yaklaşım bağlamında geleneksel duvar resimlerinden ayrılır. Aylarca süren, klasik yöntemlerle (boya, fırça) yapılan bir duvar resmine göre, sprey boyayla yapılan güncel bir uygulama çok daha kısa sürede bitirilebilmektedir. Ayrıca, stilize, illüstratif (resimlemeci) ve çizgi roman temelli bir görsel dil kullanımı da çalışmanın hızla sonuçlandırılmasını desteklemekte ve geleneksel duvar resminden farklılaşan bir görsellik ortaya çıkmaktadır.

Günümüzde küresellik ve yaygın internet iletişimi, sokak sanatçılarının dolaşıma girmesine izin vermekte, yerel yönetimlerin ve sponsorların desteğiyle, dünyanın dört bir yanında, anıtsal duvar resimleri gerçekleştirilmektedir. Ülkemizde de 'Mural İstanbul', 'Mural İzmir' projeleri ve diğer illerdeki kimi organizasyonlar aracılığıyla, ulusal ve uluslararası birçok sanatçı bir araya gelerek uygulama şansı bulmakta ve bunu halkın paylaşımına sunmaktadırlar.

$\mathrm{Bu}$ çalışmada ele alınan sokak sanatçılarının (JR, Obey gibi) birçoğu anıtsal duvar uygulamaları da gerçekleştirmektedir. Burada Brezilya'dan mural (duvar resmi) örneklerine yer verilecektir, çünkü Brezilya, sokak sanatı ve grafiti konusunda en etkileyici ve sıra dışı örnekleri barındıran bir ülkedir. Buradaki yoksulluk, ekonomik ve toplumsal sorunların doğurduğu çelişkiler, daha güçlü ve özgün bir ifade tarzının ortaya çıkmasına yol açmıştır. Bu ülkede "graffiti, dünyanın acı gerçeklerinden kaçmak için bir araçtır” (Atayurt, 2006, s. 29). Grafiti New York’tan dünyaya sızmaya başladığında,
Brezilya diktatörlük zamanından, özellikle de 60’lardan kalma özel bir geleneğe sahipti: Pichacao (piikasoo diye okunuyor). Devlet mercilerinin böyle adlandırdığı bir gotik sanat sloganı olan 'pichacao', diktatörlüğün demir ökçesi altında ezilen yoksul gençlerin icat ettiği bir başkaldırı kültürüydü. Boya dolu kovalar, iptidai fırçalarla kaçamak olarak yazılan bu duvar sanatı, Brezilya sokak ikonografisinin temelini teşkil ediyordu (Atayurt, 2006, s. 28).

1980’lerle birlikte Brezilya'da bu slogan karakterli pichacaolar başka form ve amaçlara dönüşmeye başladı ve yapanların kişiselliklerini, yalnızlıklarını ve ün kazanma isteklerini ifade etmek biçiminde varlığını sürdürdü. Bu aşamada tercih edilen dil duvar resmiydi. Os Gemeos (Portekizce; İkizler) Otavio ve Gustavo Pandolfo böyle bir ortamda çalışmalarına başladılar. Onlar, sokak aracılığıyla dinamik ve büyülü dünyalarıyla halk arasında bir bağlantı kurmanın yolunu buldular. Doğaçlama ve mizaha dayalı bir görsel dil oluşturan ikizler, karikatürle bıçak sırtı bir ilişki içinde olmalarına rağmen özgün olmayı başarabildiler (bkz. Şekil 11). Sokak çalışmalarını farklı disiplinlere de uygulayan (tuval, yerleştirme, üç boyutlu çalışmalar) ikizler bu çalışmalarını dünyanın dört bir yanındaki müze ve galerilerde sergilediler.

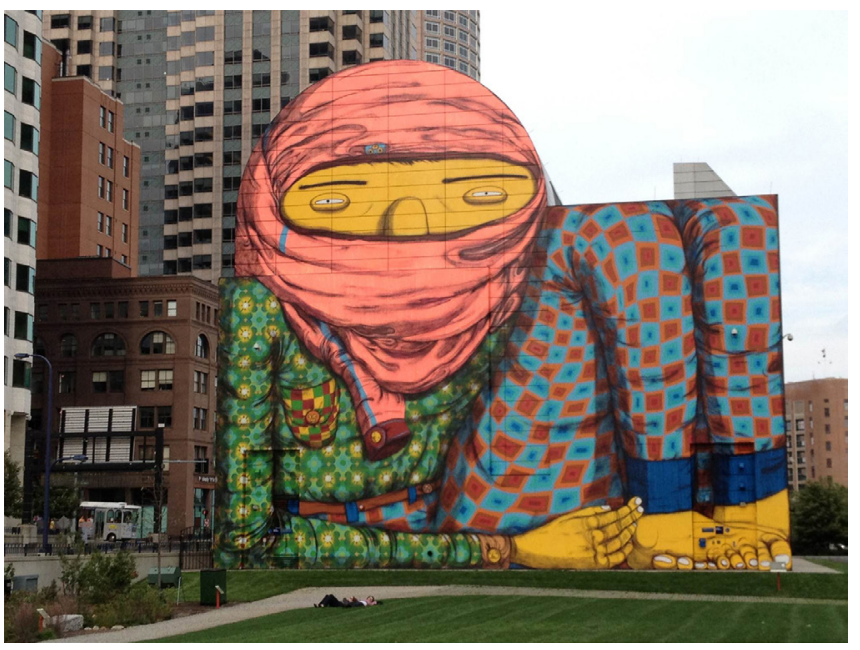

Şekil 11. İsimsiz, Os Gemeos, 2012.

Bir diğer Brezilyalı sanatçı Alexandre Orion da kendine has sokak sanatı ifade yöntemlerine sahiptir. Genellikle motorlu taşıtların yol ve tünellerde oluşturduğu kirlilik katmanlarına müdahaleleri, egzoz kirliliğinden aldığı baskıları ve şehir duvarlarına boyadığı figürlerle oradan geçenleri 
etkileşime soktuğu çalışmalarıyla bilinir. Bu konudaki en önemli projesi, çevresel kir ile akrilik baz boyayı karıştırarak oluşturduğu siyah-beyaz-gri monokrom 'duvar kirliliği' serisidir. Devasa boyutlardaki bu çalışmalar Sao Paolo, New Mexico, Rio de Janerio, Frankfurt ve Majae'de bulunmaktadır. Burada ele alınan Sao Paolo’daki ‘Tutuklama' adlı çalışmada (bkz. Şekil 12), sanatçı belli bir açıdan bakıldığında geri plandaki gecekonduyla örtüştürdüğü manzaranın önünde yine gecekondu ev oyuncaklarıyla oynayan çocuk figürüyle toplumsal sorunlara parmak basmaktadır (Orion, t.y.).

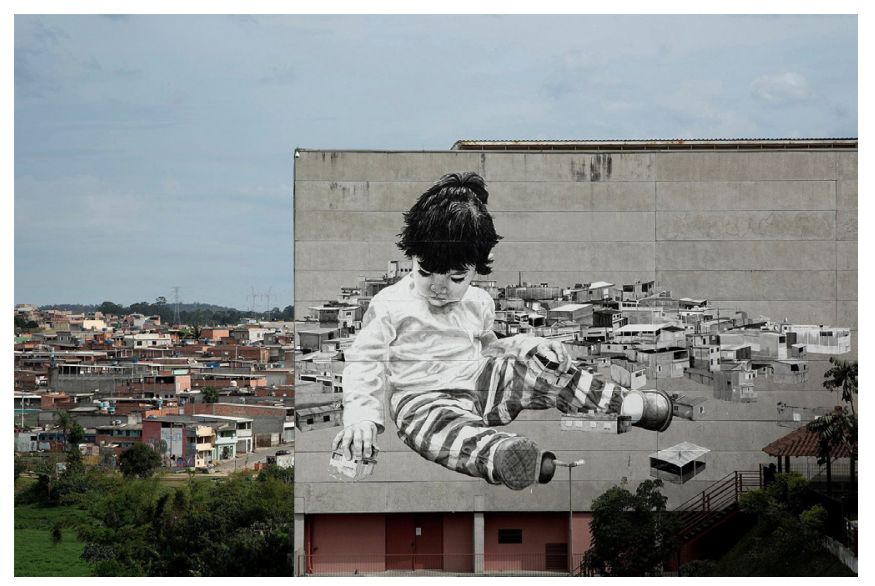

Şekil 12. Tutuklama, Alexandre Orion, 2014.

\section{Yükselen Değer Olarak Sokak Sanatı, Çağdaş bir Akım mı?} Hala Muhalif mi?

Bir karşı kültür olarak ortaya çıkan sokak sanatı, yasaklara aldırmaz, başkaldırıcı ve radikaldir. Ancak hareketin popülerliği C.Cola, Nike gibi genç kitleyi hedefleyen markaların dikkatini çeker. Bu şirketler "pazarın çekiciliğine karşı koymakta epey güçlük çeken sanatçılarla işbirliği yaparak" (Lemoine, 2014, s. 21) ve onların estetiğini kendilerine mal ederek, reklama yönelik kullanırlar. Para, popülerlik ve geçim kaygısı bu sanatçıların direncini kırmış ve "yeniyetmeliği geride bırakınca, gençliklerindeki başkaldırı, işlerini profesyonelleştirmeye yönelik meşru bir arzuya toslamıştır” (Lemoine, 2014, s. 22). Birçok muhalif sokak sanatçısı buna karşı çıkar ve bu durumu, vandal iken satılmış olmak ve davaya ihanet olarak görürler. Ancak bu işbirliği, kabul edilebilir oranda boyun eğmemeyi de destekleyen tüketim toplumunun beklentilerine uyar.

Henüz gelişmekte, sınırları ve terimleri muğlak, tartışmaya açık bir olgu olan sokak sanatı toplum tarafından benimsendikçe galerilerin, müzelerin, sanat alıcılarının ve yerel yönetimlerin dikkatini çekiyor. "Underground (yeraltı) dönemini geride bırakan graffiti ve sokak sanatı artık sadece vandalizm değil küresel bir sanat akımı olarak anılıyor ve herkesin beğenisine sunuluyor" (Ayral, 2014, s. 9). Böylece bu kurumlar bu talebi değerlendiriyor, bu sanat müzelere girebiliyor, galerilerde sergileniyor, alınıp satılabiliyor ve yeni bir isimle anılmaya başlıyor; 'Çağdaş Kent Sanatı'. Galeride sergi açmak, birçok sokak sanatçısı için amaçtan sapıldığının göstergesi olmasına rağmen, sinerji yaratan ve insanları etkileyen bu büyük hareketin sokaklarda kalmayacağı açıktı. Londra Tate Modern-2008 'Sokak Sanatı', Fondation Cartier Galerie, Paris-2009 'Sokakta DoğanGraffiti', MOCA, Los Angeles-2011 'Sanat Sokakta', Prag Kent Kütüphanesi- 2012 'Kentte Takılıp Kalmış’ ve İstanbul Pera Müzesi-2014 ‘Duvarların Dili: Graffiti/Sokak Sanatı', gibi son on yılda açılan sergiler bu harekete gösterilen ilgiyi ortaya koymaktadır. 2009 yılındaki Turner Ödülünün grafitiden gelen bir sanatçıya (Richard Wright) verilmesi de böyle bir ilgiyle bağlantılıdır. Çalışmanın yalnızca sergi için galerinin duvarına altın varakla uygulanması ve sergi bitiminde silinecek olması, hem geçiciliği savunan sanatçıları hem de bu gerçeği bilen izleyicileri mutlu etti. Çalışma dekoratif bulunsa da eleştirmenler de bu geçiciliği heyecan verici buldular ve "yaşadığımız dönemin ressamı ve sadece bizim devrimize ait çünkü kalıcı olmak istemiyor. Ne cüretkar bir bütünlük, zenginliklerin geçiciliği üzerine ne zekice bir yorum" (Jones, 2015, s. 282) gibi olumlu değerlendirmelerde bulundular. Ancak daha sonra Gagosian Galerisinin sanatçısı olan Wright'ın kalıcı çalışmalarıyla profesyonel ortamda yer alması çelişki yaratıyor. Bu çelişkiyi diğer bazı sokak sanatçıları da yaşıyor. Banksy sokak çalışmalarıyla, satış yaptığı işleri arasına mantıksal bir ayrım koyabiliyor ve hala vandal olduğunu iddia edebiliyor. Banksy’nin ünü arttıkça ve ticari başarı kazandıkça sokaktaki çalışmaları da yerinden duvarıyla birlikte sökülerek astronomik fiyatlara satılmaya başlıyor. Obey ve Futura piyasaya tasarımlar yapıyorlar ve bu durum tartışmalara yol açıyor.

Gücünü ve estetiğini bulunduğu yerden alan, yapış hızı, tekniği, adrenalin ve gelip geçicilik gibi unsurlarla var olan sokak sanatı galeriye taşındığında ve bu özelliklerinden mahrum kaldığında sorunlar başlar. Burada ruhunu yitirmemek önemlidir. Bunun için sanatçılar çözüm üretmeye çalışıyorlar. Bu bağlamda bazı sanatçılar çalışmalarının 'izlerini' sergiler, örneğin; Banksy sokak uygulamalarının 
baskılarını ve tuval boyamalarını, JR ise bağlamdaki fotoğrafların fotoğraflarını sergiler. Pignon eskizlerini ve hazırlık desenlerini, Martha Cooper belgesel fotoğraflarını galeriye taşır. Kimi galeriler sanatçılara dışarda duvarlar verirler. Pera Müzesi'nde de (2014) olduğu gibi sanatçıların doğrudan galeri duvarına kendi üslubunda uygulama yapmasına izin verilir. Müzelerde ve galerilerde sergilenen sokak sanatı çalışmaları sanatçıların "sokakta edindikleri deneyimlerden türüyor, o deneyimlerle zenginleştiriliyor ve sergi uzamında yeni bir bağlama uyarlanıyor" (Chenus ve Longhi, 2014, s. 26). Ancak galeri bağlamına taşınan bu çalışmaları profesyoneller ve eleştirmenler sokak sanatı, grafiti olarak tanımlamakta tereddüt ediyorlar.

Sokak sanatı çağdaş bir akım mı, cevabı net olmasa da evet öyle görünüyor. Bunun nedeni de günümüz modern sonrası sanat ortamındaki çok sesliliğe rağmen belirli, baskın ve sürükleyici bir akımın (kübizm gibi) olmamasıdır. Sokak sanatı yarattığı etki ve gördüğü ilgiyle, kapalı devre çalışan ve belirli bir tıkanmışlığı yaşayan günümüz sanat ortamına açııım sağladığı için akım olarak değerlendiriliyor. Daha çok çağdaş bir sanat hareketi olarak nitelendirebilecek olan sokak sanatı, hareketin tümünü kapsayan belirgin ve tek bir üsluptan çok, malzeme ve teknik yöntemlerin ön planda olduğu ifade çeşitliliğini yansıtmaktadır.

Sokak sanatı hala vandal ve muhalif bir boyuta sahip midir, bunun cevabı daha da karmaşıktır. Bütün sorunlar sokak sanatının muhalifi olduğu sisteme bulaştığı anlarda ortaya çıkmaktadır. Sistemin tuzakları; para ve şöhret, sanat fuarlarında, galeri ve müzelerdeki gösterişli sergi organizasyonlarında yer almak, siparişleri yerine getirmek şeklinde sokak sanatçısının hemen yanı başında durmaktadır. Bir sokak sanatçısı için taviz vermeden hem sistem içinde yer alıp hem muhalif ve vandal olarak kalmak büyük bir beceri gerektirmektedir. Bu konudaki en yetenekli ve beceri sahibi sokak sanatçısı, tartışmalı da olsa Banksy'dir. Bu çalışma boyunca ele alınan birçok sanatçı bunu dengesini kurmak için belirli bir çaba sarf etmektedir. Legal ya da illegal olsun sokakta bir çalışma gerçekleştirip onu her türlü dış müdahaleye ve doğal yıpranmaya açık halde kendi geçiciliğiyle baş başa bırakmak bile başlı başına muhalif bir sanatsal tavırdır. Başta İngiltere olmak üzere birçok ülkede grafiti ve sokakta izinsiz çalışmak hala yasak. Bu nedenle izin almaksızın gerçekleştirilen her bir sokak sanatı uygulaması, siyasi bir içeriğe sahip olsun ya da olamasın hala muhalif, hala vandaldır.

\section{Sonuç}

90'ların başından itibaren etkisini hissettirmeye başlayan sokak sanatı, 2000'li yılların ortalarıyla birlikte profesyonel sanat ortamı da dâhil, herkesin ilgi gösterdiği bir sanat hareketine dönüştü. Bunda, internet iletişim ağlarının küresel ölçekte yaygınlaşması ve sokak sanatçılarının bu kanalı etkili bir biçimde kullanarak dolaşıma girmelerinin de payı vardır. Sokak sanatı, özellikle Banksy aracılığıyla müzelere dahi gitmemiş yeni bir izleyici kitlesi oluşturdu. Sokak Sanatının underground ve muhalif boyutu, karşı durduğu sistemle temasa geçtikçe (reklamlar, sergi organizasyonları, legal uygulamalar vb.) sorunlar ve tartışmalar ortaya çıktı. İllegalliği savunan radikal sokak sanatçıları, sistemle uzlaşma gibi görünen legal uygulamaları davaya ihanet ve satılmışlık diye yorumlarken, diğerleri çalışmalarının estetik kalitesini arttırdığı ve mesajlarını daha iyi iletmelerini sağladığı için bunda bir sakınca görmediler. Sistem tarafından ehlileştirilme sorunuyla yüz yüze olan sokak sanatçıları bunu aşmaya çalışıyor. Bu nedenle hem sokakta iş üretip bunu gelip geçiciliğe havale eden hem de galeriye dönük çalışan sanatçılar, sokak deneyimlerinden türeyen çalışmalarını sergileyerek, yaşadıkları çelişkiyi en aza indirmeye çalışıyorlar. Sokak sanatçısının en temel çelişkisi, muhalif, vandal olmak ve anonim kalmakla, gördüğü ilgi aracılığıyla sistemin imkanlarından yararlanarak güncel bir sanatçı olmanın arasında kalmaktır.

Şu anda gündemde olan ve rağbet gören sokak sanatçısı, uzun vadede bir stüdyo sanatçısının çalışmasıyla rekabet edebilir mi, bu gelecekte yanitlanması gerekecek sorulardan birisidir. Akım olarak adlandırılmakta zorlanılan bu sanat, kent sanatı, kentsel çağdaş sanat gibi adlandırma çabalarıyla belirli bir isimlendirme zorluğuyla da karşı karşıyadır. 'Kentsel Çağdaş Sanat' adlandırması, kapsamı genişleterek radikal veya değil, ironik ya da siyasal eğilimleri ve tüm sanatçıları "uzlaştırıp, sanatı bütünüyle 21. yüzyıla özgü bir okumada bir araya toplar" (Chenus ve Longhi, 2014, s. 28). Şu anda sokaktan türeyenleri de kapsayan ve çağdaş sanat ortamında dolaşımda olan benzer nitelikteki çalışmalar için belki de en uygun adlandırma bu olabilir.

Son bir söz daha söylemek gerekirse, sanat uzun zamandır toplumsal çevreden kopuk, dar ve kapalı bir çevrede sıkışmış durumdadır. Sokak sanatı, sanatın sokağa taşınması ve insanların yaşamının bir parçasına dönüşmesi anlamında önemli bir işlevi de yerine getirmektedir. Bu hareketin ilgiyle karşılanmasının önemli bir sebebi belki de budur. 


\section{Kaynakça}

Atayurt, U. (2006). Konu: Post graffiti; Os Gemeos, ikimiz birimiz, birimiz hepimiz için. Bant Dergisi,19, 22-39.

Ayral, R. (2014). Duvarların dili: graffiti/sokak sanatı. Bahar T., Çolakoğlu F., Ataç A. ve Soley U. (Ed.), Duvarların dili graffiti) Sokak sanatı içinde (s. 9-16), İstanbul: Pera Müzesi Yayını.

Banksy. (2006). Maid in London / Londra'da hizmetçi. Erişim Adresi: https://curiator.com/art/banksy/maid-in-london

Baudrillard, J. (2016). Simgesel değiş tokuş ve ölüm, (Çev. Oğuz Adanır), İstanbul: Boğaziçi Üniversitesi Yayınevi.

Baykam, B. (2016). From Graffoman to street art, İstanbul: Piramid Yayıncılık / Yer altı Kuşağı 2.

Blek Le Rat. (2008). Uyuyan adam [Grafiti]. Leake street, London. Erişim Adresi: https://upload.wikimedia.org/wikipedia/ commons/4/4c/Blek_le_Rat_-_Sleeping_man.jpg

(t.y.). Biography. Erişim Adresi: https://urban-nation. com/artist/blek-le-rat/

C215/Guemy, C. (2014). Graffiti, sokak sanatı, muralissimo... Birbirine karıştırmasak artık şunları. Bahar T., Çolakoğlu F., Ataç A. ve Soley U. (Ed.), Duvarların dili graffiti/Sokak sanatı içinde (s. 31-37). İstanbul: Pera Müzesi Yayını.

Cheneus, N. ve Longhi, S. (2014). Çok biçimli bir akım: Kentsel çağdaş sanat. Bahar T., Çolakoğlu F., Ataç A. ve Soley U. (Ed.), Duvarların dili graffiti/Sokak sanatı içinde (s. 25-28). İstanbul: Pera Müzesi Yayını.

Ellsworth Jones, W. (2015). Banksy; duvarın ardındaki adam (Çev. Esra Mert). İstanbul: Hayalperest Yayınevi.

Evol. (2009). Caspar David Friedrich- Stadt I. Erişim Adresi: https://ny.voltashow.com/archive/2011/exhibitors-2011/ wilde-gallery/evol/

Futura/Futura 2000. (t.y.). İsimsiz [Resim]. Erişim Adresi: https:// www.widewalls.ch/futura-exhibition-urban-spree/

Güngör, A. ve Sanaç, E. (2006). Konu: Post graffiti; Tristan Manco. Bant Dergisi, 19, 22-39.

Invader. (2013). Paris’te yeni istilalar. Erişim Adresi: https:// streetartnews.net/2013/12/invader-new-invasions-inparis-december.html

(t.y.). About. Erişim Adresi: https://www.space-invaders. com/about/

JonOne (2016). Gözlerini aç. Büyük Grafiti Sergisi, Kore, Erişim Adresi: http://koreajoongangdaily.joins.com/news/article/ article.aspx?aid $=3027456$

JR. (2015). Kentin kırışıklıkları. İstanbul. Erişim Adresi: https:// octopodartdotcom.wordpress.com/2017/03/05/sehrinkirisikliklari/

(t.y.). Biography. Erişim Adresi: https://jr-art.net/about

Lemoine, S. (2014). Müzeye bir karşı kültür: Kuruma meydan okuyan kent sanatı. Bahar T., Çolakoğlu F., Ataç A. ve Soley u. (Ed.), Duvarların dili graffiti/Sokak sanatı içinde (s. 1923). İstanbul: Pera Müzesi Yayını.

Mimaroğlu, İ. (2002). New York kapı dışı sanatı. İstanbul: Yapı Kredi Yayınları- İzdüşümler/Düş İzleri-3.

Obey (1999). Pasteup, Unknown, Erişim Adresi: https:// cranbrookartmuseum.org/2018/03/05/cranbrook-artmuseum-announces-summer-exhibitions-fast-live-youngdie-punk-graphics-1976-1986-shepard-fairey-saladdays-1989-1999/

Orion, A. (2014). Tutuklama. Sao Paulo. Erișim Adresi: https:// streetartbrasil.wordpress.com/2015/01/10/the-20-bestmurals-of-2014/

(t.y). Bio. Erişim Adresi: https://www.alexandreorion.com/ poluicaosobremuro

Os Gemeos (2012). İsimsiz, ICA Boston. Erişim Adresi: https:// gohighbrow.com/os-gemeos/

Swoon.(2009). İsimsiz. Erişim Adresi:https://norwegianstreetart. files.wordpress.com/2010/05/p1030660.jpg

(t.y.). About. Erişim Adresi: https://swoonstudio.org/about

Zeus. (2012). About. Erişim Adresi: http://www.deanzeuscolman. com/about/4567902851

.(t.y.). 3D Duvar. Erişim Adresi: http://www.deanzeuscolman. com/paintings/4583942365 